\title{
Hunchun, the Qing-Chosŏn Borderland in the Eighteenth Century*
}

Kim Seonmin**

\section{Introduction}

At the break of dawn on November 16th of the 14th year of Emperor Qianlong (December 25th, 1749), a man reached Mijan Karun located 50 $l i$ to the northwest of Hunchun. Wearing little more than a summer jacket and pants in the middle of winter and with his hands and shoeless feet frozen stiff, the man collapsed after having failed to answer questions. Instead of dispatching him to the Hunchun Yamen, Plain Yellow Banner Company Captain Dersu, the man in charge of Mijan Karun, decided to look after this unidentified unconscious person who had just appeared out of nowhere in his karun. In anticipation of his visitor's awakening, Dersu and his men conducted a search of the immediate area around Karun. However, the snow having already melted, he found himself unable to find any traces of this mysterious man. When the visitor finally woke up on November 25th (January 3rd, 1750), he informed his hosts that his name was Dzeng Gungliyang and that he had been on his way home with six other people and four horses from a trip to the mountains in which the focus had been the "illegal" collection of ginseng. He stated that one night

\footnotetext{
* This work was supported by a National Research Foundation Grant provided by the Korean Government (MEST)" (NRF-2007-361-AL0013).

** Associate Professor, Research Institute of Korean Studies, Korea University.
} 
when they were camped along the banks of the Mukdehe River near the Tumen River a group of men suddenly appeared. Once it became clear that these men were intent on taking their lives, Dzeng Gungliyang took flight toward the Mijan Karun. On November 26th (January 4th, 1750), a group of men returning from Ningguta came across three horses without saddles on the side of the road, and immediately took these horses to the Mijan Karun. It was eventually confirmed that these horses were the property of Dzeng Gungliyang and his party. ${ }^{1}$

Dersu reported the incident to Acting Regiment Colonel of Hunchun Baksina on November 26th (January 4th, 1750), and reported that Dzeng Gungliyang could not go out to find his companions and remaining horse because of the frostbite on his feet. Upon taking notice of this report, Baksina dispatched Lieutenant Dasingga to Mijan Karun. Having provided Dzeng Gungliyang with a hat and gloves, Dersu and Dasingga joined him in a sled-based expedition to look for the missing members of his party in the area along the Mukdehe Rive located several $l i$ from the Mijan Karun. ${ }^{2}$ At the foot of a mountain located to the northwest of the Mukdehe River, they discovered two charred huts and five corpses scattered around the huts. All the corpses had wounds on their faces and heads consistent with having been struck with axes. While all five men had been scalped, with their bone marrow exposed, the skin on the faces of four of the men had also been ripped off, leaving behind only the bones. There were no traces of the other person and horse described by Dzeng Gungliyang. The huts in which the corpses of Dzeng Gung Liyang's

1 Hunchun fudutong yamen dang(Records of the Office of the Hunchun Lieutenant General), edited by Zhongguo bianjiang shidi yanjiu zhongxin and Zhongguo diyi lishi dang'anguan (Guangxu shifan daxue chubanshe, 2007), vol. 2, 1617.Hunchun fudutong yamen dang is hereinafter referred as to Hunchun dang.

2 While Dasingga of Hunchun reported the distance from the Mukdehe River as "40li", the Head of the Mijan Karun, Dersu, claimed it to be no more than "several li (m. $u d u b a$ )". A member of Dzeng Gung Liyang's party disappeared, with his corpse discovered later on. The body was found in a place called Hūlanggi šeri located some $30 l i$ away from the Mijan Karun. 
companions were discovered were located $3 l i$ from the hills marking the entrance to the Tumen River. In this regard, a small village belonging to Chosŏn known as Yuwŏn Garrison was located across the river to the southwest some 3 liaway. $^{3}$

This incident, which emerged within the jurisdiction of the Hunchun Yamen located near the Tumen River, was frequently discussed by the Regiment of the Colonel of Hunchun and the Lieutenant General of the Ningguta Garrison until June of the 15th year of the Qianlong Emperor. Upon having been informed by the Mijan Karun that ginseng diggers from Ningguta had been killed near the Tumen River, the Hunchun Yamen sent a report to the Lieutenant General of the Ningguta Garrison. It also dispatched banner soldiers to the scene of the incident to investigate the surroundings. The Lieutenant General of the Ningguta Garrison in turn instructed that the victims be identified and that clues that could help the capture of the suspects be found. Furthermore, he also ordered that he be frequently informed of how the investigation was unfolding. The twenty Manchu reports related to the Dzeng Gungliyang incident submitted by the Hunchun Yamen to the Ningguta Yamen from January to June of the 15th year of the Qianlong Emperor are included in Volume 2 of Hunchun Fudutong Yamendang (Records of the office of the Hunchun Lieutenant General).

Meanwhile, the news that several Qing subjects had been killed near Chosŏn's Yuwŏn Garrison that lay across the Tumen River made its way to local Chosŏn government officials via the people of Hunchun. This incident, which subsequently came to be known as 'Kim Insul Murder Case in Onsŏng,' was also reported to the court of Chosŏn in Seoul on January 5th during the 15th year of Emperor Qianlong (February 11th, 1750) through the Magistrate of Onsŏng Prefecture and the Governor of Hamgyŏng Province. The Chosŏn court arrested the Chosŏn people involved in this incident and immediately reported this fact to the Qing

3 Hunchun dang 2, 18-20. 
court. Rather than via the Hunchun Yamen which exercised jurisdiction across the Tumen River where the incident emerged, the Choson court's report on the Kim Insul incident was delivered to the Beijing Board of Rites through the Fenghuangcheng Military Commander and the Shengjing Board of Rites located across the Yalu River. The twenty Chinese reports on this matter exchanged between Chosŏn and Qing are included in the Tongmun hwigo (Collection of the Same Language Materials).

Based on reports contained in the Hunchun dang and Tongmun hwigo, this study reconstructs the incident in which Qing ginseng diggers were murdered near the Tumen River on November $16^{\text {th }}$ of the 14 th Year of Emperor Qianlong (December 25th, 1749) as well as the subsequent beheading of the criminals along the border of suspects from Chosŏn on May $10^{\text {th }}$ of the 16th year of Emperor Qianlong (July 2nd, 1751), or some eighteen months after the original incident. First, this study traces the whereabouts of Dzeng Gungliyang and his companions as they came down from the mountains following their journey to extract ginseng, entered Hunchun, and encountered Chosŏn inhabitants near the Tumen River. Next, it analyzes the manner in which the Hunchun Yamen dealt with this incident once it became aware that a group of ginseng diggers had been murdered within its jurisdiction. This study intends to explain that ginseng diggers in the Tumen River area as well as banner soldiers from Hunchun frequently came into contact with Chosŏn people, with whom they respectively engaged in commercial transactions and discussed matters related to border market management. The main interests of the Ningguta Yamen, whose power superseded that of the Hunchun Yamen, were to identify the victims, uncover those responsible for these heinous crimes, and find the best way to deal with the properties left behind by the victims. Meanwhile, the Chosŏn court sought to ensure that the murders along the border did not cause any problems in its relationship with Qing. To this end, it focused on promptly reporting the situation to Beijing through Fenghuangcheng. Through a review of how government officials from Qing and Chosŏn gathered in Fenghuangcheng 
to investigate this incident, it analyzes the manner in which Beijing and Seoul perceived this instance of murder that occurred along their collective border. By delving more deeply into the situation that prevailed in the Tumen River area, Hunchun, and Fenghuangcheng at this time, this study seeks to show that the relationship between Qing and Chosŏn was one that involved various actors engaged in a multilayered manner.

\section{The Tumen River}

A man named Dzeng Gungliyang from Shandong Province began to be engaged in the collection of ginseng after meeting a person named Lio Madzi. Lio Madzi was originally a sailor of Heilongjiang Province (m. sahaliyan šuruci). Having escaped from his home area during the thirdyear of Emperor Qianlong, Lio Madzi was placed on a list of fugitives (m. ukan). Little is known about his whereabouts after he ran away from Heilongjiang. However, some ten years after his initial flight, or by the 14th year of Emperor Qianlong, Lio had become a resident of Ningguta and a legal ginseng collector who had obtained a ginseng license from the Yamen. ${ }^{4}$ In May of that same year, Lio Madzi met Dzeng Gungliyang in Ningguta and convinced him to help him collect ginseng with him. Thereafter, Lio Madzi and Dzeng Gungliyang, as well as other members of their crew, left for the Andaogu area with four horses, grains and a rifle. They collected 40 liang of ginseng and 12 liang of ginseng roots during this particular foray. ${ }^{5}$

A man named Yetai who served as guarantor when Lio Madzi received his ginseng license, later stated to the Yamen that although there were eight names on the original license, names that included the likes of Lio Meijy, Peng Huwalin and Han Da, he was unsure whether Dzeng Gungliyang was one of them. He postulated that Dzeng had perhaps

\footnotetext{
4 Hunchun dang 2, 84-85.

5 Hunchun dang 2, 21.
} 
illegally been added to the license during the trip to gather ginseng. ${ }^{6}$ For his part, Dzeng Gungliyang stated that he was with Peng San, Jeo Hiyadzi, Yang San, and G'o San when they first arrived in the Tumen River area. ${ }^{7}$ However, both the Hunchun Yamen and Ningguta Yamen found no proof that Dzeng Gungliyang was included on the ginseng license that had been guaranteed by Yetai. ${ }^{8}$ Han Da, whose name appeared first on Lio Madzi's ginseng license, returned to Ningguta once the grain ran out. However, there is no way to ensure that the seven people that travelled to Hunchun with Lio Madzi were in fact included on his ginseng license. The whereabouts of Lio Madzi, Han Da, and Dzeng Gungliyang have raised the possibility that while the ginseng collectors legally received their ginseng licenses, they then proceeded to illegally use them. There were many instances in which the names of the ginseng collectors listed on the ginseng license were unclear. There were also people who returned to a ginseng gathering after having stopped for some time to attend to personal matters. Others simply joined halfway without even bothering to register as a ginseng collector. As such, people who collected ginseng across Manchuria knew many methods to avoid detection and control by the state.

After having descended from the mountains following their ginseng gathering, Lio Madzi, his companions, and their horses arrived in Hunchun. Needing grain and grass to feed his companions and horses, Lio visited the home of an acquaintance named G'o Lio on November 3rd of the 14th year of Emperor Qianlong (December 12th, 1749). Lio Madzi was accompanied to G'o Lio'shouse, where he stayed for five days with one person, four horses, and an empty cart. He also purchased $5 \mathrm{dou}$ of grain from G'o Lio for his companions. Lio Madzi suggested, "I will

6 Hunchun dang 2, 70. 72.

7 The Chinese characters for Dzeng Gungliyang as well as the names of his companions can be found in Chosŏn records. Tongmun hwigo (Collection of the Same Language Materials), (Kuksa p'yŏnch'an wiwŏnhoe, 1978), vol. 2, 1084a.

8 Hunchun dang 2, 84. 
exchange silver for some grain now. You should give me more grain if I obtain a ginseng license and come back here again next year. If I don't get the ginseng license, then I will come back to take back some of my silver." Lio Madzi provided G'o Lio with 9 liang and 2 qian of silver. On November 8th (December 12th) Lio Madzi left along with the four horses and the person he had arrived with. ${ }^{9}$ They then headed to Si Fanlii's house. A civilian from Shandong, Si Fanlii was also known as Lii Siyang. Lio Madzi'sgroup had in the meantime swelled to four people and five horses. They stayed at Si Fanlii's house for five days. He left on November 12th (December 21st), promising Si Fanlii 2 liang in return for the latter's provision of accommodation upon his return to Ningguta. ${ }^{10}$

During his stay at Si Fanlii's house, Lio Madzi traded horses and silver with two bannermen from Hunchun. A soldier from the Bordered Yellow Banner named Yališan recalled seeing a grayish white horse, owned by Lio Madzi, in Si Fanlii's yard on November 9th (December 18th). Yališan proposed to trade the white horse with his own black horse, saying thatthe white horse had grown too thin and was suffering from an undisclosed injury that made it difficult for it to reach Ningguta. The two men reached an agreement and proceeded with the swap. On November 11th (December 20th), Lio Madzi resold Yališan's black horse, which he had exchanged for his white horse. Another soldier from the Bordered Yellow Banner named Taisungga decided to purchase the black horse for 8 liang of silver, making a down payment of 4 liang of silver and 2 dou of grain. He promised to pay for the rest (2 liang of silver) next year when he visited Lio Madzi in Ningguta. ${ }^{11}$

After leaving Si Fanlii's house on November 12th (December 21st), Lio Madzi and his companions headed for the Mukdehe River area near the Tumen River the next day. It was here that Lio Madzi encountered Chosŏn residents. Local soldiers from the Yuwŏn Garrison in Onsŏng

9 Hunchun dang 2, 133. 195-196.

10 Hunchun dang 2, 134.

11 Hunchun dang 2, 170-71. 
Prefecture named Kim Insul, Kim Tusŏk, and Chang Sŏnggun were on their way to Daedonggu across the Tumen River to look for firewood. Having run out of grain, Lio Madzi and his companions suggested to the Korean soldiers that they proceed to trade cotton for grain. Although Kim Insul was aware that his counterpart was a ginseng collector from Ningguta, he did not know Lio's name or where he was from. In all fairness, Kim did not need to know names or hometowns to exchange ginseng products with ginseng collectors from the neighboring country. Later that night, Kim Insul and his men crossed the Tumen River again with barley and soy beans in hopes of exchanging them with Lio Madzi for cotton fabrics and deer skin. At that moment, Lio Madzi and his companions suggested that they trade more grain for ginseng that he arguably had in his packages. Kim Insul and a few others once again crossed the Tumen River on November 14th (December 23rd), this time bringing with them 9 dou of rice. However, the trade did not proceed as smoothly as the day before. Kim Insul later recalled, "After having received the rice, the Qing ginseng collectors refused to give us the agreed upon ginseng and cotton and proceeded to physically assault us."12

With the fact that they had not only been insulted by Lio Madzi and his companions, but had refused to pay them for their grain, the angry local Chosŏn soldiers decided to take revenge on the perpetrators of these perceived affronts. Kim Insul, Kim Tusŏk, and Chang Sŏnggun told four local soldiers (Chang Hani, Chang Huch'ang, Chang Kwian, and Kim Hyŏngsam) about what had happened, and the group made plans to recover their belongings. On the night of November 15th (December 24th), they proceeded to the Qing ginseng collectors' huts. WhileKim Insul was armed with an ax, Chang Huch'ang had a gun, and Kim Tusŏk, Chang Sŏnggun, Chang Hani, Chang Kwian, and Kim Hyŏng sam boasted cudgels. When they came across the Qing group, Lio Madzi and the six others were lying down in two huts as a fire roared in the

12 Hunchun dang 2, 1080a. 
background. Upon hearing the blank shots fired by Chang Huch'ang, Lio Madzi and the others ran out of their respective huts in shock. There ensued a melee in which Kim Insul killed two people with his ax and another with a cudgel after Kim Hyŏngsam had incapacitated the man with his own cudgel. Meanwhile, Kim Tusŏk and Chang Huch'ang killed another two men. For their part, Chang Sŏnggun, Chang Hani, and Chang Kwian chased after and killed another man. During the melee, the huts caught fire and burnt to the ground. The Chosŏn soldiers split the ginseng, rice, cotton, silver, and clothes that had not been destroyed by the fire amongst themselves. ${ }^{13}$

Chosŏn and Qing residents were strictly prohibited from privately crossing the Yalu and Tumen Rivers. Residents along the border area were rigorously forbidden from gaining access to the other's territory by crossing the river for the purpose of engaging in acts such as ginseng poaching, logging, hunting or commercial transactions. In 1637, shortly after the establishment of the tributary relationship with Chosŏn, Hong Taiji implored the Chosŏn court to return Chinese people who had sought refuge in Chosǒn. ${ }^{14}$ In 1712, Emperor Kangxi ordered the General of Shengjing to arrest any person found to have been illegally involved in hunting or fishing along the land or sea borders, and granted Chosŏn government troops the authority to arrest any trespassers from Qing. ${ }^{15}$ In 1722, Qing allowed the Chosonn soldiers to punish Qing residents who had travelled to Chosŏn without a proper certificate and caused incidents. ${ }^{16}$ When a group of Qing people crossed the Yalu River and proceeded to kill Chosŏn troops during the $5^{\text {th }}$ year of Emperor Yongzheng, one of the

13 Hunchun dang 2, 1083b-84b. Seven local Chosŏn soldiers including Kim Insul provided information about the process that led up to the killing of Lio Madzi and the others after their arrest. Hunchun dang 2, 1080a-83b.

14 Qinding Da Qing huidian shili (Collected Statutes and Precedents of the Great Qing), (Shanghai guji chubanshe, 1995), 511:1a.

15 Hunchun dang 2, 1183b; Qinding Da Qing huidian shili, 511:4a.

16 Hunchun dang 2, 1183b-84a; Qinding Da Qing huidian shili, 511:5b. 
criminals was subsequently beheaded while the other eight were hung in the public square. ${ }^{17}$

While illegal to privately cross the Tumen River, such a trek became legal when one obtained a permit from the government. Shortly after Hong Taiji's first attack on Chosŏn in 1628, a border market began to take form in the Chunggang (Zhongjiang) area along the Yalu River. ${ }^{18}$ Qing also required that trade be opened up in the Hoeryŏng area of the Tumen River, and a border market did in fact begin to operate in the area from that December onwards. ${ }^{19}$ Following Hoeryŏng, another border market also opened in the Kyŏngwŏn area located across Hunchun, in 1646. While the border market in Hoeryŏng opened every year, its counterpart in Kyŏngwŏn only opened once every two years, and this only from December to January. The border market in Kyŏngwŏn was also called the 'Yachun market,' or, because it was located in the northern area of Chosŏn, the 'Pukkwan market.' Regulations for the border market in Hoeryŏng and Kyŏngwŏn were established in 1660, with limits placed on the number of participants and horses and cows as well as the days one could stay (20 days).

17 Tongmun hwigo 2, 1191a-b. For more on the Guo Lianjin Incident during the $5^{\text {th }}$ year of Emperor Yongzheng, see Kim Seonmin, "Ongjŏngje ŭi sŏnggyŏng chiyŏk t'ongch"' (The Rule of Emperor Yongzheng in the Shengjing Area), Myŏngch'óngsa yŏn'gu (Studies of Ming-Qing History) 34 (2010).

18 Manbun rōtō(The Old Manchu Archives), translated and annotated by Mambun Rōtō Kenkyūkai shakuchū (Tōyō bunko, 1955-63), vol.4, 111-113; 116-118; 119122.

19 Chosŏn replied to Qing's demands that a border market be opened in Hoeryŏng by stating that such a market had in the past existed when many Wark a tribes resided in the area where six garrisons were located. However, such markets ceased to exist when the Wark a tribe disappeared. In addition, Chosonn stressed the difficulties involved with the management of separate border markets along the Yalu and Tumen Rivers; however, such calls fell on deaf ears. Manbun rōtō 4, 125126; QingTaizong shilu (Veritable Records of the Qing Taizong), (Zhonghua shuju, 1986), 4, 58:b. 
However, as one could go in the morning and return in the evening, with only a river separating it from the border market in Kyŏngwŏn, Hunchun proved to be an exception to these regulations. ${ }^{20}$ Following the establishment of the Hunchun Yamen in 1714, it became commonplace for banner officers to take part in the border market through interpreters. While they did not provide any special treatment to the merchants of Hunchun, Kyŏngwŏn provided food and animal feed for the banner officers of Hunchun, interpreters and their servants. In exchange for their hospitality, the banner officers of Hunchun provided their hosts with deer pelts. As trade was limited to Hunchun, there were fewer items traded in the official market in Kyŏngwŏn than at the border market in Hoeryŏng. However, a wider variety of items were traded in the private and horse markets. $^{21}$

As mentioned above, Kim Insul and the others were able to cross the Tumen River to meet Lio Madzi and his people and exchange grain and

20 Tongmun hwigo 1, 861b; Kaksa tŭngnok(Records of Various Bureaus), "Hamgyŏngdo Hoewŏn gaesi jŏngrye" (Regulations for Border Markets in Kyŏngwŏn and Hoeryŏng in Hamgyŏng Province),(Kuksa p'yŏnch'an wiwŏnhoe, 1990),vol. 48, 487-488.

21 Terauchi Itaro "Kyŏngwŏn kaisi to konshun," ( The BorderMarkets of Kyŏngwŏn and Hunchun), Tohogaku (Eastern Studies), 70 (1985); Terauchi Itaro, "Kinsei ni okeru Chōsen hokkyo to Chūgoku: Hamgyŏngdo no kokkyŏn kōeki wo Chūsin ni" (Korea's trade with China along its northern border in Hamgyong during the early modern period), Chōsen shi kenkyūkai ronbunshü(Japanese Studies on Korean History) 36 (1998); Guo Qingtao, "Shilun shiqi shiji zhongye zhi shiba shiji Qingchao yu chaoxian de Hui Yuan bianshi maoyi” (Qing-Chosŏn Trade in Border Markets in Kyŏngwŏn and Hoeryŏng during the mid-1 $17^{\text {th }}$ century $-18^{\text {th }}$ century), Hanguoxue lunwenji ( Selected Papers on Korean Studies) 6 (1997); Ko Sŭnghŭi, Chosŏn hugi hamgyŏngdo sangŏp yŏn'gu (A Study on Commerce in Hamgyŏng Province during the late Chosŏn), (Kukhakcharyowŏn, 2003); Zhang Jie, "Qing qianqi jilin manzu yu chaoxian bianjing maoyi lunshu" (Border Trade between the Manchus in Jilin and Chosŏn during the early Qing Era), Zhongguo bianjiang shidi yanjiu (China's Borderland History and Geography Studies) 20:4 (2010). 
cotton fabrics. Such meetings were simplified by the fact that the Qing people in the Hunchun area and the Chosŏn people in Kyŏngwŏn, Onsŏng, and Yuwŏn frequently encountered one another in common spaces such as the border market in Kyŏngwŏn. Furthermore, when Kim Insul and his group's plans to exchange rice for ginseng went awry, the decision was made to hatch a plot to exact revenge on the offending Qing people. This proves that conflict also frequently emerged between the Qing and Chosŏn people. In other words, the extent of the revenge exacted by Kim Insul and his group reflect the frequency and depth of the exchanges that took place between the people of Qing and Chosŏn. The barter attempted by Kim Insul and Lio Madzi was an example of the wider daily exchanges that took place between the Qing and Chosonn people. The violence that led to the death of six people was an extreme outcome of the frequent contact between the residents that lived along the border between these two countries.

Dzeng Gungliyang had already taken off his clothes and shoes and fallen asleep by the time Kim Insul and his group fell upon his companions. Having been awoken by the blood curdling sounds of 'people dying,' Dzeng Gungliyang proceeded to crawl out of the hut and run away towards Mijan Karun. ${ }^{22}$ He lost consciousness shortly after arriving at Mijan Karun on November 16th (December 25th), and only came to on November 25th (January 3rd, 1750). Travelling by sled, Dzeng Gungliyang guided the Qing soldiers to the huts where they had stayed along the Mukdehe River. Realizing the seriousness of the situation when he discovered the corpses of Lio Madzi and the others, the head of Mijan Karun Dersu beganto press Dzeng Gungliyang for details about what had happened. Too weak to walk on his own, Dzeng Gungliyang was propped up by another person so that he could be interrogated. During the ensuing interrogation, he went into detail about how he had met Lio Madzi and came to Hunchun, and also gave the

22 Hunchun dang 2, 21. 
names of the six other people who had come with him. Dersu questioned him about such matters as to where these men were from, their appearances, and how old they were. However, Dzeng Gungliyang became unable to talk any further after he vomited what he had previously drunk. He eventually died on December 2nd (January 9th, 1750). ${ }^{23}$

How was Dzeng Gungliyang dressed as he wandered throughout the nightin the deep cold of winter? One can get an idea of his attire from the corpses of his companions. One such corpse was discovered some $30 \mathrm{li}$ from Mijan Karun two months after the murders along the Mukdehe River. The dead man was wearing pants made out of old cloth, and old sheepskin coat, a red outer garment, a white cloth kneeling wrapper, and worn out cowhide shoes. He also had a flint and tobacco pouch attached to a navy blue cotton belt. ${ }^{24}$ In a frenetic hurry to get away from Kim Insul and his group, Dzeng Gungliyang left his hut without bringing any coat or shoes with him. Although he managed to evade the axes of the local Chosŏn soldiers, his thin pants and garments proved to be no match for the bitter winter weather that prevailed in the Tumen River area.

\section{Hunchun}

Dispatched from the Hunchun Yamen, Lieutenant Dasingga was able to identify the location of the huts near the Mukdehe River with the help of Dzeng Gungliyang. Dasingga also observed that the site where the corpses were discovered lay close to Chosŏn's Yuwŏn Garrison. After seeing footprints in the snow heading in that general direction, Dasingga decided to visit the Chosŏn outpost across the Tumen River. Dasingga

23 Hunchun dang 2, 22-23. The magistrate of Onsŏng Cho T'aeŏn's explanation of the death of Dzeng Gungliyang differed somewhat. "A person who had run away naked died two days later of cold and starvation." Tongmun hwigo 2, $1974 \mathrm{~b}$.

24 Hunchun dang 2, 50-51. 
and seven others arrived in Onsŏng on December 3rd of the 14th year of Emperor Qianlong (January 10th, 1750) and proceeded to ask for interpreters and military officials. ${ }^{25}$ They asked questions to the people of Onsŏng, "An incident emerged that has left five Qing people dead by the banks of the Mukdehe river, with the victims having been stripped of their ginseng, hats, coats, guns, pots and axes. Given the general proximity, our people must have passed through your village. Do you know any of them? Did any of your people commit this heinous crime?" The Chosŏn people answered that they did not know the people who had crossed the river. They also stressed the fact that people were forbidden from crossing the river. Having failed to find the criminals, Dasingga and his men dug holes and buried the corpses in wooden frames. ${ }^{26}$

The incident was finally reported to the Hunchun Yamen on November 26th (January 4th, 1750), some 10 days after Dzeng Gungliyang had first ran to the Mijan Karun on November 16th (December 25th, 1749). The Company Captain of the Hunchun Yamen Baksina summoned the head of the Mijan Karun Dersu and reprimanded him for his misdeeds. Located along the main road between Ningguta and Hunchun, responsibility for Mijan Karun was shared by the Lieutenant General of the Ningguta Garrison and the Hunchun Yamen. In addition, the coastal area of the Tumen River, including the Mukdehe River area, was under the jurisdiction of Mijan Karun. Nevertheless, Dersu was held responsible for illegal ginseng diggers having snuck into his jurisdiction and for the subsequent deaths of some of these individuals. Furthermore, he had proven himself incapable of resolving the incident as soon as Dzeng Gungliyang reached Mijan Karun. The conclusion was reached that even though Dzeng Gungliyang had lost his speech, Dersu should have been able to find his previous whereabouts simply by tracing his footprints in the fresh snow. Above all, although he knew that people had been killed near the Tumen River, Dersu waited 10 days to report the incident to the

25 Tongmun hwigo 2, 1074a.

26 Hunchun dang 2, 20-21 
Hunchun Yamen. This led the Hunchun Yamen to rebuke the officers and soldiers operating within this jurisdiction for their incapability and irresponsibility. ${ }^{27}$

During the early Qing period in which no agency responsible for the management of Hunchun had been established, local Kurka residents were reorganized to put under the control of village heads (m. gašan i da) and paid tribute to the Qing court. The Ningguta Amban Janggin established in 1653 was made responsible for the area all the way to Hunchun, which lay some 360 li to the southeast. The Ningguta Amban Janggin was promoted to Ningguta General in 1662. Its name was subsequently changed to the General of Jilin after the dwelling of the Ningguta General was relocated to Girin Ula. A Garrison Lieutenant General (m. meiren i janggin) was installed in Ningguta following the departure of the Ningguta General. As such, Hunchun fell under the jurisdiction of theLieutenant General of the Ningguta Garrison. A banner garrison was officially installed in Hunchun in 1714. It organized the Kurka people into three niru, and appointed three niru i janggin, three lieutenants and 150 soldiers. The organized niru were divided into the Bordered Yellow Banner, Plain Yellow Banner and Plain White Banner. The Regiment Colonel (m. gūsa $i d a$ ) was placed in charge of general affairs in the Hunchun area. The Regiment Colonel of Hunchun was a level three military official whose work duties were determined by orders from the Lieutenant General of the Ningguta Garrison. As such, those who held this position did not have any authority to report directly to the General of Jilin or the Emperor. ${ }^{28}$

\section{Hunchun dang 2, 24.}

28 Qing shengzu shilu ( Veritable Records of the Qing Shengzu), 257:548a; Baqi tongzhi chuji (First Edition of the History of the Eight Banners), (Dongbei shifan daxue chupanshe, 1989), 27; Wu Yuanfeng, "Qingdai Hunchun xieling fudutong yamen ji qi manhan dang'an" (The Manchu and Chinese Archives of the office of the Hunchun Regiment of the Colonel and Lieutenant General during the Qing Era), Dongbei minzu yanjiu ( Study of Minorities in Northeast China), (Liaoning 
It is not clear when Baksina first reported the incident to the Lieutenant General of the Ningguta Garrison. However, the Lieutenant General of the Ningguta Garrison had already received an initial report on the incident from Jibkio, who succeeded Baksina. In this regard, Jibkio submitted an official report to the Ningguta Yamen in the name of Baksina on January 14th of the 15th year of Emperor Qianlong (February 20th, 1750). Although there were many problems with the handling of the incident, including the delay in reporting the Dzeng Gungliyang Incident and the lack of clarity in terms of the main actors involved with the report, Baksina, Jibkio and the other officials in Hunchun nevertheless paid very close attention to the characteristics of this incident. It in reality involved two crimes, namely murder and the illegal collection of ginseng. Both crimes were felonies prohibited by the state. The Hunchun Yamen decided to launch an investigation into the first and last names, as well as the hometowns and appearances, of Dzeng Gungliyang and his group. In addition, although the victims were illegal ginseng diggers operating without a proper ginseng license, their murderers had to be brought to justice. After having decided to look after Dzeng Gungliyang's three horses within the Hunchun Yamen, Jibkio dispatched Dersu to arrest the criminals. He also discussed how to handle the corpses and three horses with the Lieutenant General of the Ningguta Garrison. ${ }^{29}$

The Hunchun Yamen continuously contacted Chosŏn officials while awaiting instructions from the Ningguta Yamen. Having looked over Jibkio's report to the Lieutenant General of the Ningguta Garrison, Dasingga in Hunchun decided to visit Onsŏng in Chosŏn on December $3^{\text {rd }}$ of the 14th year of Emperor Qianlong (January 10th, 1750). This was followed by a visit from an official from Kyŏngwon to Dersu in Mijan on February 7th (March 14th, 1750). Thereafter, Jibkio also crossed the Tumen River to meet with officials from Kyŏngwon on February 14th (March 21st). As such, officials from Hunchun and Kyŏngwon contacted

minzu chubanshe, 2007), vol. 1, 77-81.

29 Hunchun dang 2, 26. 
one another on three occasions. However, according to a report which was sent to the Qing court by King Yŏngjo of Chosŏn on January $9^{\text {th }}$ of the 14th year of Emperor Qianlong (February 15th, 1750), between December 19th and $23^{\text {rd }}$ of the 14th year of Emperor Qianlong (January 26th-30th, 1750) the Magistrate of Onsŏng Prefecture Cho T'aeŏn and the Magistrate of Kyŏngwon Prefecture An Chip investigated the incident along with "officials from the superior court," and subsequently submitted a report to Seoul. The Kyŏngwon soldiers cooperated with their counterparts from Hunchun in their investigation of the towns and garrisons near the Tumen River. They immediately arrested five of the local soldiers from the Yuwŏn Garrison, namely Chang Hani, Chang Sŏnggun, Chang Huch'ang, Kim Insul and Chang Kwian. Kim Tusŏk and Kim Hyŏngsam were also arrested later. ${ }^{30}$

Jibkio's report did not clearly indicate when he came to know about the arrest of the Chosŏn soldiers. However, Jibkio dispatched Baksina and Budei to meet the four officials and two interpreters from Kyŏngwon who visited the Tumen River area to discuss the matter. ${ }^{31}$ The Kyŏngwon officials had the following to say to Baksina and Budei.

After the border market opened in Kyongwon last year, there began to emerge stories among the people of Hunchun and Chosŏn stating, 'Chosŏn people had killed (people) across the river from the Yuwon Garrrison.' Upon hearing about this...(omitted).... Choson officials summoned all the men of Yuwon, it was discovered that three men were actually missing. These three men were subsequently arrested in Ongšan (Onsŏng) and investigated, 'you must have run away after killing these people'. However, no further details were provided. Do you know the victims across the Yuwŏn?

30 Tongmun hwigo 2, 1074a; $1075 \mathrm{~b}$.

31 The positions and names of the Kyŏngwon officials are included in Jibkio's records, but the accuracy of the related Chinese characters cannot be confirmed. "bing fang hafan pu dung ceng, šao guwan hafan gin si giyang, ping ma ciyan jiyei i li hafan, nan jai ji." Hunchun dang 2, 42. 
How many were killed? What kinds of articles did they have? How did you handle this incident? Did you report this incident to the higher authorities? Did you release the fact that Choson people were responsible for these deaths when you reported the incident to the higher authorities? ${ }^{32}$

The officials of Chosŏn also revealed that they had been dispatched by the Governor of Hamgyŏng Province and were investigating the incident in accordance with instructions from Seoul. Baksina and Budei informed them that while they did not have any instructions from the Ningguta Yamen, they were aware that an incident involving seven men with four horses, 45 liang of ginseng, and 12 liang of ginseng roots had occurred. They also related how one of the men had managed to run away to Mijan Karun. Moreover, while five corpses and three horses had been found, the whereabouts and fate of the last man and horse remained unknown. ${ }^{33}$

The actions taken by the Qing and Chosorn officials guarding their common border separated by a river after the corpses were discovered along the banks of the Tumen River belie some interesting aspects of Qing- Chosŏn relations. For instance, while Dasingga in Hunchun, who discovered the corpses in the huts in Mukdehe, immediately visited the Korean outpost across the river to inquire about the incident, Cho T'aeŏn of Onsŏng and An Chip of Kyŏngwon engaged in frequent discussions about the incident with Qing soldiers. Moreover, after Kyŏngwon officials visited Dersu in Mijan Karun, Baksina from Hunchun paid a return visit to the Kyŏngwon officials. All of these moves show that officials and soldiers from both sides regarded contact and cooperation with one another as a natural process. The depth of the information shared by the two sides about the incident points to the existence of close relationships. In this regard, the officials from Hunchun and Kyŏngwon should be perceived as having regularly come into contact with one another via the border market in Kyŏngwon and through their cooperative

32 Hunchun dang 2, 43.

33 Hunchun dang 2, 62-63, 80-81. 
efforts to manage and control those who crossed the river either legally or illegally. Despite the clear border between the two countries and their need for interpreters, the Qing and Chosorn officials based in the Tumen River area were close to one another. Contrary to the perceptions of Emperor Qianlong in Beijing and King Yŏngjo in Seoul, Chosŏn and Qing were not foreign countries to men like Jibkio of Hunchun and An Chip of Kyŏngwon. They were in fact neighbors.

According to Baksina, Jibkio failed to report the Chosŏn officials' visit to discuss the incident to the Ningguta Yamen because the "explanations provided by the Chosonn officials were not exact." Jibkio informed the Regiment of Colonel Tunghai, who had been dispatched from Girin Ula and arrived in Hunchun on February 12th (March 19th). ${ }^{34}$ Jibkio and Tunghai met directly with Chosŏn officials along the banks of the Tumen River on February 14th (March 21st). Two officials from Kyŏngwon and two interpreters proceeded to explain the situation to the Qing officials on behalf of An Chip who had taken ill. ${ }^{35}$ The Kyŏngwon officials informed their Qing counterparts that they had arrested all seven of the criminals, and that this fact had been reported to Seoul on February 6th (March 13th). The names of the Chosonn people who had committed the murders were also provided to Jibkio and Tunghai. The Chosŏn officials also said that a heretofore unknown small package of silver had been discovered among the clothes taken by the criminals. ${ }^{36}$ After having ascertained these

\section{Hunchun dang 2, 63.}

35 The positions and names of the officials from Kyŏngwon are included in Jibkio's records, but the accuracy of the Chinese characters cannot be confirmed. "ts'o šeo hafan dzai ing mi, bing fang hafan han sio ho" (Hunchun dang 2, 43). At the time, the magistrate of Onsŏng was Cho T'aeŏn, the Assistant Commander of Yuwŏn Yi Sihwa, the magistrate of Kyŏngwon An Chip, the governor of Hamgyŏng Province Chŏng Ikha, and the Army Commander Ku Sŏngp'il. Tongmun hwigo 2, 1074a-b.

36 According to a report from the Chosŏn King to the Qing Board of Rites of Qing on February $30^{\text {th }}$ of the 15th year of Emperor Qianlong (Tongmun hwigo and Qing shilurecorded dates based on the lunar calendar, under which a $53 \%$ possibility of a 
facts, Jibkio finally submitted the report to the Ningguta Yamen on February 14th (March 21st). ${ }^{37}$

Meanwhile, on February 15th (March 22nd) soldiers from Mijan Karun discovered a corpse near the location where Dzeng Gungliyang and his companions' three horses had been set free. A person was found lying face down in a field near Hūlanggi šeri, some 30 li away from Mijan Karun located east of the main road to Ningguta. A white wool hat was found laying next to his head. While his right hand was placed under his chest, his left hand was grasping soil. While the skin on the shoulders had been damaged to an extent that the bones were exposed, the skin below the shoulders had turned yellow. No other injuries were evident. The soldiers of Mijan Karun estimated that the man had died in October of the $14^{\text {th }}$ year of Emperor Qianlong. ${ }^{38}$ No other details about the man were released. However, considering the location where the corpse was discovered and the fact that the man's skin had turned yellow, we can rightfully conclude that this man was Dzeng Gungliyang's companion who had disappeared from the huts in Mukdehe. As such, all of the other six people who had harvested ginseng with Dzeng Gungliyang were found dead.

While he informed the people under his jurisdiction that the dead person had to be identified, Jibkio could not find anyone who recognized the deceased. ${ }^{39}$ Although the corpses discovered in November were buried in a hole, it could not be left as it was because of the impending spring. Furthermore, as it had been buried in a narrow and steep mountain, it was possible for wild animals to dig up the corpse at night. As such,

February 30 exists). one of the criminals named Kim Kwian took a piece of clothes from Dzeng Gungliyang in which seven pieces of silver were subsequently discovered. The silver weighed a total of 20liang and 32qian. Tongmun hwigo 2, $1075 \mathrm{~b}$.

37 Hunchun dang 2, 42-44; 63-64.

38 Hunchun dang 2, 50-51.

39 Hunchun dang 2, 51. 
Jibkio made the decision to bring the corpse to Mijan Karun on February 26th (April 2nd). He reburied the body and then ordered his soldiers to guard it. ${ }^{40}$ However, the dead proved to be only one of the matters he had to look after. One of the three horses that had been discovered along the road died at the end of February. One of the remaining two horses was a white horse with a grayish hue that had been stamped with a soldering iron. It was believed to be almost 20 years old. The other horse was black and approximately15 years old. One of its ears had been cut. Having made the determination that they were too thin to send to Ningguta, Jibkio ordered that the remaining two horses be looked after within the Hunchun Yamen. The decision was at that time also made to send the horses to the Ningguta Yamen in the spring once they had been fattened up. ${ }^{41}$

\section{Fenghuangcheng}

Upon being informed about the Dzeng Gungliyang incident, the Lieutenant General of the Ningguta Garrisonordered that steps be taken to ensure that criminals had been arrested and that the victims had possessed a ginseng license issued by the government. ${ }^{42}$ The Ningguta Yamen discovered that there were problems with Company Captain of Hunchun Yamen Jibkio's handling of the incident. He dispatched Jibkio to investigate the reason for the lateness of Baksina's report on the murder case that had emerged within his jurisdiction. However, Jibkio found himself unable to reveal the details of the incident even after he had arrived in Hunchun. He even submitted a report in the name of Baksina

40 Hunchun dang 2, 57.

41 Hunchun dang 2, 56-57.

42 Hunchun dang 2, 54. Having received the report about the Dzeng Gungliyang incident via the Lieutenant General of the Ningguta Garrison, the Jilin General instructed the Hunchun Yamen to reconfirm the entire story and to promptly return the revised document in a sealed envelope. Hunchun dang 2, 45-46. 
who was a former Regiment Colonel of the Hunchun Yamen. In addition, although Jibkio should have been able to gain a strong grasp of the facts following the visit by officials from Kyŏngwon on February 7th (March 14th) and promptly reported these facts to the Ningguta Yamen, he held off on doing so until five days after Tunghai had arrived in Hunchun on February 12th (March 19th). ${ }^{43}$

It was Baksina, and not Jibkio, who was in charge of Hunchun when Dzeng Gungliyang went to Mijan Karun on November $16^{\text {th }}$ of the 14th year of Emperor Qianlong (December 25th, 1749). Baksina, who was Acting Regiment Colonel of Hunchun at the time, received the initial report from Dersu. He then ordered that a preliminary investigation that included providing Dzeng Gungliyang with clothes and a sled to search for the criminals be conducted. Jibkio was appointed as Regiment Colonel of the Hunchun Yamen on January 7th of the 15th year of Emperor Qianlong (February 13th, 1750). As the Dzeng Gungliyang incident emerged before his appointment, Jibkio was aware that Baksina had already submitted a first report on the matter. Believing it wrong to affix his name on a report that was based entirely on Baksina's information, Jibkio's report sent to the Ningguta Yamen on January 4th (February 20th) was rendered in the name of his predecessor. ${ }^{44}$ Despite having met with officials from Kyŏngwon on February 7th (March 14th) to hear about the information they had collected to date, Jibkio held off for some time on submitting his own report. He only submitted his report after having comprehensively analyzed the meetings with the officials from Kyŏngwon he held on February 7th and 14th. Moreover, as Tunghai had already obtained the names of the criminals from the Chosŏn side and gotten a solid grasp on the situation, he did not feel that he had to "write down all the detailed information he had secured from the Chosonn officials. $^{45}$

43 Hunchun dang 2, 60-61.

44 Hunchun dang 2, 16-26.

45 Hunchun dang 2, 64. 
Once they confirmed that the criminals who killed Dzeng Gungliyang and his companions were Chosŏn people and that the perpetrators had already been arrested, the main focus of the Lieutenant General of the Ningguta Garrison shifted to the identification of the victims and the handling of their possessions. The investigation and punishment of Chosŏn criminals was to be carried out by the Chosŏn court, and not the Ningguta Yamen.

These grisly murders that emerged near the Tumen River were reported to the Chosŏn court in Seoul. After having grasped the seriousness of situation and arrested the criminals, Seoul proceeded to contact the Qing court through Fenghuangcheng along the Yalu River where the royal envoys of Chosŏn were located, rather than through Hunchun, under whose jurisdiction the Tumen River area fell. While the arrest of five local soldiers from the Yuwŏn Garrison took place at the end of December of the 14th year of Emperor Qianlong, the Governor of Hamgyŏng Province Chŏng Ikha and the Commander-in-Chief of Hamgyŏng Province Ku Sŏngp'il decided to report this incident to King Yongjo on January 5th of the 15th year of Emperor Qianlong (February 11th, 1750). ${ }^{46}$ Upon being informed that Chosonn people had entered the territory of Qing and killed five Qing people, King Yŏngjo dispatched Kim Yumun as a royal emissary to Beijing on January 9th (February 15th) and charged him with reporting to the Qing Boad of Rites. ${ }^{47}$ King Yŏngjo dispatched Special Inspector for the Northern Provinces Sŏ Chisu to investigate the murder case. Sŏ was dispatched again in February to conduct a further investigation of the site. ${ }^{48}$ King Yŏngjo also dispatched Sŏ as a special envoy to Qing to report on the incident on February 14th

46 The incident in which Kim Insul and his companions killed the Qing nationals is also introduced in the T'ongmun'gwan chi(Records of the Office of Translators), translated by Sejong daewang ginyŏm saŏphoe, (Sejong daewang ginyŏm saŏphoe, 1998), vol.2, 267.

47 Tongmun hwigo 2, 1075a.

48 Chosŏn yŏngjo sillok (Annals of Chosŏn King Yŏngjo), 71:3a, 71:9b. 
(March 21st). ${ }^{49}$ On February $30^{\text {th }}$, King Yŏngjo sent Han Ch'ihyŏng as a royal emissary and tasked him with reporting on all the facts they had collected up until that point. Han reported that the seven local soldiers from the Yuwŏn Garrison who had participated in the murder of the Qing peoplehad been arrested and seven pieces of silver had been discovered from the clothes taken by Kim Kwian. In addition, Han also reported that the Governor and Commander-in-Chief of Hamgyŏng Province had put the silver and objects stolen by the criminals into storage until further instructions had been secured from the Qing court. ${ }^{50}$

The Qing court appears to have been well aware of Chosŏn's intentions to promptly respond to this matter and to sincerely report the whole story. The Qing Board of Rites showed its appreciation for Han Ch'ihyŏng's efforts by awarding himwith 30 liang of silver during the latter's visit to Beijing. In addition, it also provided 8 liang of silver to one interpreter, 4 liang of silver to ten attendants, and a banquet for the Chosŏn envoys. ${ }^{51}$ The efforts of the Chosŏn court were clearly compensated during the process of punishing the criminals. On March 12th (April 18th), Emperor Qianlong ordered that the case in which Chosŏn people killed six people of Qing subjects 'be handled in accordance with the precedents set during the Yongzheng and Qianlong periods'. This meant tha Kim Insul and his conspirators, as well as the local governors of Onsŏng and Kyŏngwon, would be taken to Fenghuangcheng, where officials from the Qing Board of Military and from the Chosŏn court would jointly investigate the criminals on behalf of Qing and Chosǒn. ${ }^{52}$

Chosŏn people's trespassing on Qing territory was a serious issue that historically caused tension between Beijing and Seoul. This matter was dealt with differently across periods. During the Hong Taiji Era, an imperial messenger was dispatched to Seoul to investigate an instance in

49 Tongmun hwigo 2, 1075a.

50 Tongmun hwigo 2, $1075 \mathrm{~b}$.

51 Tongmun hwigo $2,1079 \mathrm{~b}$

52 Tongmun hwigo 2, 1076a. 
which Chosŏn people were arrested for having illegally gathered ginseng on the Qing side of the Yalu and Tumen Rivers. This incident resulted in the criminals being executed along the river banks and the local governor being removed from the position. During Emperor Kangxi's era, two officials from Qing were dispatched to Fenghuangcheng to meet with Chosŏn officials and jointly investigate incidents in which Chosŏn people crossed the river to cut down trees, dig up ginseng and steal from civilians. ${ }^{53}$ During the reigns of Emperor Yongzheng and Qianlong, it was common practice to send criminals and local governors to the Fenghuangcheng whenever Chosŏn people crossed the border and were arrested. Joint investigations by officials from the Qing Board of Rites and the Chosŏn court were also the norm. Following a review by the Chosŏn king and report to the Qing Board of Rites, the determination of the punishment to be meted out to the Chosŏn criminals was finally reached with the approval of the Qing emperor. ${ }^{54}$ Rather than unilaterally investigated by Qing officials, Chosŏn people who committed crimes on Qing territory were jointly investigated by the two countries. Thus, as the relationship between Qing and Chosŏn became more stable from the early 18th century onwards, the punishment of Chosŏn people who crossed the border also gradually became more regulated.

While the Lieutenant General of the Ningguta Garrison grappled with the issue of how to handle the property of Lio Madzi, the Chosŏn court was busy transferring Kim Insul and his companions from Kyŏngwŏn to Fenghuangcheng. On April 14th (May 19th), King Yŏngjo dispatched Royal Secretary Nam T'aegi to Fenghuangcheng as an investigator. Furthermore, the Chosŏn court strictly ensured that Kim Insul and his

53 Qingding da qing huidian shili, 511:4b.

54 For more on the issueChosŏn subjects illegally gaining access to Qing territory and the investigation of such matters, see Wang Yanjie, Qingchao qianqi yu chaoxian bianwu jiaoshe yu hezuo yanjiu(A study on negotiation and cooperation between Qing and Chosŏn on boundary affairs), PhD dissertation, Shandong University, 2012. 
companions not change what they had said to Korean officials during the investigation that would take place in front of the Qing officials in Fenghuangcheng. It also prepared for the joint investigation a Fenghuangcheng by threatening Kim Insul and his companions, "If there are any discrepancies in your statements, your wife, children and parents will die." ${ }^{, 55}$ In addition, they avoided condemnation for any perceived delay in the criminals' transfer to Fenghuangcheng by informing the Qing court beforehand that it would take some time to transfer the criminals from the Tumen River area to the Fenghuangcheng across the Yalu River. On April 24th (May 29th), King Yŏngjo informed the Shengjing Board of Rites that the criminals, Kim Insul, Chang Sŏnggun, Kim Tusŏk, Chang Huch'ang, Chang Hani, Chang Kwian, and Kim Hyŏngsam, would be transferred to Fenghuangcheng under the authority of the Magistrate of Onsŏng Cho T'aeŏn. ${ }^{56}$ As such, the Chosŏn court was very careful in its handling of instances involving Chosŏn people's illegal entry to Qing territory and murder cases.

A joint investigation into the actions of the seven Chosorn soldiers was launched by La-lung-ga of the Shengjing Board of Punishment, Guan-bao of the Beijing Board of Punishment, and the Chosorn Royal Secretary Nam T'aegi on May 10th (June 13th). The results of this investigation were made known to the Shengjing Board of Rites and King Yŏngjo on May 26th (June 29th). The 27 year-old ringleader Kim Insul was found to belong to the Yuwŏn Garrison. Kim admitted to killing Lio Madzi and his companions and to taking their belongings, and maintained that he did not know who the victims were. Kim said that although he saw a rifle and four horses he decided to leave them there for fear that it would make it easier for others to recognize them. He also stated, "The Qing people told us that they would exchange ginseng for rice. However, I never saw any ginseng at the huts on the night of the 15th." Similar statements were made by the other six people. However, all the others with the exception

55 Chosŏn yŏngjo sillok (Annals ofChosŏnKing Yŏngjo), 71:15b.

56 Tongmun hwigo 2, 1078a. 
of Kim Insul stressed that they had not seen any rifle. ${ }^{57}$

Guan-bao submitted apetition to Emperor Qianlong on June 3rd (July 6th) calling for the punishment of Kim Insul and his companions in accordance with examples set during the Kangxi era. Based on the opinion of Guan-bao, Emperor Qianlong ordered 'that the criminals and local magistrates be sent to Chosŏn so that the king of Chosŏn can deal with the accordingly. ${ }^{58}$ Instead of being chastised and held responsible for his failure to rule his own people, King Yŏngjo was granted the authority to determine the penalty to be meted out and subsequently suggest it to the Qing emperor. This was the result of six months of efforts on the part of the Chosonn court to avoid friction with the Qing court by promptly and carefully handling the incident. On December $26^{\text {th }}$ of the 15th year of Emperor Qianlong (January 23rd, 1751), King Yŏngjo suggested to Emperor Qianlong that Kim Insul and his companions receive the following punishment. "Although there are differences in the severity of the crimes committed by these seven people, all of them illegally crossed the border and committed brutal crimes. As such, all the criminals shall be executed, their wives and children shall be made slaves, and their family fortunes shall be forfeited. The Governor of Hamgyŏng Province Chŏng Ikha and Commander-in-Chief Ku Sŏnghyŏn shall be removed from their positions for having allowed local soldiers under their jurisdiction to trespass the border and commit this crime. The Magistrate of Onsŏng Cho T'aeŏn shall be deposed from his position and exiled to a place some 2,000 li away for having made it possible for his people to commit such crimes by failing to thoroughly investigate the happenings in the area under his control." The Chosŏn court also provided articles which the criminals had taken away from the Qing victims such as black

57 Kim Tusŏk was 28, Chang Sŏnggun 36, Chang Huch'ang 46, Chang Hani 38, Chang Kwian 33, and Kim Hyŏngsam 26. All of them were local soldiers from the Yuwŏn Garrison. They did not have any kinship relations to each other. Tongmun hwigo 2, 1080a-83b.

58 Tongmun hwigo 2, 1083a-84b. 
cotton, sheepskin coats, silver, deerskins, knives, axes, and a rifle. ${ }^{59}$

Based on the Chosŏn king's suggestion, Emperor Qianlong meted out the final sentence for the seven criminals and local governors on March $17^{\text {th }}$ of the 16th year of Emperor Qianlong (April 12th 1751). The Qing court also added, "considering the immediate manner in which the criminals were arrested and reported to the court, the Chosŏn king shall be exculpated from any guilt." ${ }^{, 60}$ Kim Insul and his six companions were executed along the border on May $10^{\text {th }}$ of the 16th year of Emperor Qianlong (July 2nd, 1751), one year and six months after Lio Madzi and his people were murdered near the Tumen River. ${ }^{61}$ On August 16th (October 4th), King Yŏngjo informed Emperor Qianlong that the criminals had indeed been executed. Furthermore, while it was only natural for the king to be held responsible for the 'residents of a small country' spurred to commit such felonies by starvation and coldness, King Yŏngjo expressed his great appreciation to the benevolent emperor for having exculpated him from such responsibility. ${ }^{62}$

\section{Conclusion}

Border trespassing has consistently occurred across time and place. In their seminal study on the borders between numerous countries, Michiel Baud and Willem van Schendel reached the following conclusion: "No matter how clearly borders are drawn on official maps, how many customs officials are appointed, or how many watchtowers are built,

59 Tongmun hwigo 2, 1086a-87a.

60 Tongmun hwigo 2, 1087a-88a.

61 Chosŏn yŏngjo sillok (Annals of Chosŏn King Yŏngjo), 73:23b. It is not clear in which "border" they were executed. However, the fact that the investigations were implemented in Fenghuangcheng would seem to lend some credence to the theory that the execution took place near the Yalu River rather than the Tumen River.

62 Tongmun hwigo 2, $1088 \mathrm{~b}$. 
people will ignore borders whenever it suits them. In doing so, they challenge the political status quo of which borders are the ultimate symbol." $" 63$ A state intends to control the movement of people and to exercise its sovereignty by dividing border crossings into legal and illegal actions in order to counter borderland residents' attempts to render these regulations null and void by encroaching on the boundary. As such, there inevitably emerges a conflict between the desires of people who intend to encroach on these boundaries and the will of state power to control such desires. "From the perspective of national centers of authority, the border between countries is a sharp line, an impenetrable barrier. But from the perspective of the border, borderlands are broad scenes of intense interactions in which people from both sides work out everyday accommodations based on face-to-face relationships. In this way, the study of borderlands implies a critique of state-centered approaches that picture borders as unchanging, uncontested, and unproblematic."64

Various aspects of Qing-Chosŏn relations can be uncovered by approaching the borderland in the Tumen River and Hunchun as a place where people from various classes expressed their desires and negotiated with one another, rather than as a place where the will of central power was conveyed and penetrated. The emperor in Beijing and the king in Seoul respectively sought to ensure the authority of the suzerain court and the loyalty of tributary courts along the Tumen and Yalu Rivers. The boundary was supposedly a line where these central powers could clearly divide the hierarchical order between suzerain and tributary courts. It was meant to be a clearly fixed line for the state authority where the hierarchical order of suzerain and tributary countries was reflected and applied. The control of borders and punishment of those that encroached on it were therefore very important for the Qing emperor and Chosŏn king when it came to expressing and maintaining their power. Viewed

63 Michiel Baud and Willem van Schendel, "Toward a Comparative History of Borderlands," Journal of World History 8:2 (1997), 211.

64 Baud and van Schendel, "Toward a Comparative History of Borderlands," 215-16. 
from the standpoint of Beijing and Seoul, the Tumen and Yalu Rivers were a political space where the hierarchical tributary relationship that existed between the Qing and Chosŏn courts could be visualized.

However, for the local soldiers of Chosŏn in Yuwŏn Garrison and the ginseng collectors of Qing from Ningguta, the Tumen River was not a place where the boundary between the suzerain and tributary courts was divided. It was a place where they could gain profit by selling articles or a remote place where they could stay several days out of the reach of government soldiers. Although they could not converse with one another, the people across the river traded articles on a regular basis. The Tumen River was as such too narrow and shallow to reflect the weight of the emperor's authority and the suzerain-tributary order.

It was the mission of government officials to transform the Tumen River into an impenetrable border and to exhibit the authority of the Qing emperor and Chosŏn king via the control of this border. However, the contacts that took place between the banner officers of Hunchun and local officials in Kyŏngwŏn were very different from the hierarchical suzeraintributary order as expressed in Beijing and Seoul. The words of Chosŏn kings to Qing emperors were prepared in a rigid documentary manner and delivered by a high ranking official of Chosŏn serving as a royal envoy. The documents delivered by the royal envoy of Chosonn were submitted to the Beijing Board of Rites and then reported to the emperor after going through Fenghuangcheng and Shengjing Board of Rites. Meanwhile, the encounters between the banner officers of Hunchun and local officials from Kyŏngwŏn were not based on documentation. Armed with interpreters, they visited each other across the Tumen River whenever an incident occurred. They frequently came into contact with each other to exchange information and to share news from Seoul. Hunchun and Kyŏngwŏn were much closer to one another than Beijing and Seoul. As such, the relationship between the officials in Hunchun and Kyŏngwŏn was much closer than that between the Qing emperor and Chosón king.

A look at the contacts and conflicts that emerged in the Tumen River area and the process through which this incident was handled helps shed 
some light on the role played by a plurality of people from various walks of life in the establishment of relations between Qing and Chosŏn. Emperor Qianlong in Beijing, Baksina in Hunchun, Dersu from Mijan Karun, and Lio Madzi of Ningguta all belonged to Qing. Meanwhile, King Yŏngjo, An Chip of Kyŏngwŏn, Cho T'aeŏn of Onsŏng, and Kim Insul of the Yuwŏn Garrison all belonged to Chosŏn. However, the relationship between Emperor Qianlong and King Yŏngjo differed from that between Baksina and An Chip. The relationship between Lio Madzi and Kim Insul was even more unique. If King Yŏngjo was for Emperor Qianlong the king of a loyal tributary state who voluntarily obeyed the authority of Qing, then Kim Insul was a local person who could help Lio Madzi overcome his shortage of food. While King Yŏngjo had never directly met Emperor Qianlong, Kim Insul met Lio Madzi face to face to talk to him and trade articles. While the relationship between Yŏngjo and Qianlong was formal, indirect and ideological, the relationship between Kim Insul and Lio Madzi was detailed, direct and physical.

This fact implies that the Qianlong-Yŏngjo and Lio Madzi-Kim Insul relationships cannot be lumped together as part of an overarching 'QingChosŏn relationship.' In other words, the Qing-Chosŏn relationship that developed along the border was carried out in a multilayered manner. The states and groups generalized as "Qing" and "Chosŏn" were in actuality composed of disparate units whose various interests transformed QingChosŏn relations into a complex web that was never linear or simple. Based on numerous incidents such as the one between Lio Madzi and Kim Insul who met, fought, and lived together along the Tumen River, one can critically review the conventional narratives of suzerain-tributary relations centering on the emperor of Qing and king of Chosǒn and develop a new perception of the multilayered and complicated relations between Qing and Chosŏn. 


\section{References}

1. Baqi tongzhi chuji (八旗通志初集), Dongbei shifan daxue chupanshe, 1989.

2. Baud, Michiel and Willem van Schendel, "Toward a Comparative History of Borderlands," Journal of World History 8:2 (1997).

3. Guo Qingtao (郭慶濤), “Shilun shiqi shiji zhongye zhi shiba shiji Qingchao yu chaoxian de Hui Yuan bianshi maoyi” (試論17世紀中 葉至18世紀清朝與朝鮮的會源邊市貿易), Hanguoxue wenji(韓國學 論文集) 6 (1997).

4. Hunchun fudutong yamendang (琿春副都統衙門檔). Edited by Zhongguo bianjiang shidi yanjiu zhongxin (中國邊疆史地歷史中心) and Zhongguo diyi lishi dang'anguan (中國第一歷史檔案館). Guangxu shifan daxue chubanshe, 2007.

5. Kaksa tŭngnok (各司謄錄), vol. 46, Hamgyŏngdo Hoewŏn gaesi jŏngrye (咸鏡道會源開市定例), Kuksa p'yŏnch'an wiwŏnhoe, 1990.

6. Kim Seonmin(Kim Sŏnmin), “Ongjŏngje ŭi Sŏngkyŏng jiyŏk t'ongch'i”(Emperor Yongzheng's rule in the Shengjing Area), Myŏngch 'ŏngsa yŏn'gu(History of the Ming-Qing Eras)34 (2010).

7. Ko Sŭnghŭi, Chosŏn hugi Hamgyŏngdo sang'ŏp yŏn'gu(Commerce in Hamgyŏng Province During Late Chosŏn), Kukhak charyowŏn, 2003.

8. Manbun rōtō (滿文老檔), translated and annotated by Mambun Rōtō Kenkyūkai shakuchū (滿文老檔研究會譯註), Tōyō Bunko, 1955-1963.

9. Qinding Da Qing huidian shili(欽定大淸會典事例). Shanghai: Shanghai guji chubanshe, 1995.

10. Qing Shilu (清實錄). Beijing: Zhonghua shuju, 1986.

11. Terauchi Itaro (寺內威太郎), “Kyŏngwŏn kaisi to konshun,” (慶源開 市と琿春, Tōhōgaku 東方學), 70 (1985).

12. Terauchi Itaro (寺內威太郎), “Kinsei ni okeru Chōsen hokkyo to Chūgoku: Hamgyŏngdo no kokkyŏn kōeki wo Chūsin ni” (近世にお ける朝鮮北境と中國: 咸鏡道の國境交易を中心に),

Chōsensi 
kenkyūkai ronbunshū (朝鮮史研究會論文集), 36 (1998).

13. Tongmun hwigo (同文彙考). 3 vols. Kuksa p'yŏnch'an wiwŏnhoe, 1978.

14. T'ongmun gwanji (通文館志), translated by Sejong daewang ginyŏm saŏphoe, Sejong daewang ginyŏm saŏphoe, 1998.

15. Wu Yuanfeng (吳元豊), “Qingdai Hunchun xieling fudutong yamen ji qi manhan dang’an” (清代琿春協領副都統衙門及其滿漢文檔案), Dongbei minzu yanjiu (東北民族研究) 1, Liaoning minzu chupanshe, 2007.

16. Wang Yanji (王燕杰), Qingchao qianqi yu chaoxian bianwu jiaoshe yu hezuo yanjiu (清朝前期與朝鮮邊務交涉與合作研究), $\mathrm{PhD}$ dissertation, Shandong University, 2012.

17. Zhang Cunwu (張存武), Qing Han zongfan maoyi 1637-1894 (淸韓 宗藩貿易) 1637-1894, Taiwan Zhongyang yanjiuyuan jindaishi yanjiusuo, 1985.

18. Zhang Jie (張杰), “Qing qianqi jilin manzu yu chaoxian bianjing maoyi lunshu” (淸前期吉林滿族與朝鮮邊境貿易論述), Zhongguo bianjiang shidi yanjiu (中國邊疆史地研究), 20:4 (2010). 
$<$ Abstract $>$

\section{Hunchun, the Qing-Chosŏn Borderland in the Eighteenth Century}

Kim Seonmin

Based on a murder which emerged near Hunchun in 1749 , this study analyzes the varied and complex nature of the Qing-Chosŏn relationship. The local residents residing along the border, local officials guarding the border between both countries, and the Qing emperor and Chosŏn king were all involved in this murder in which Qing subjects were killed by Chosŏn people along the Tumen River. However, this incident was differently perceived in the Tumen River area, Hunchun, Beijing and Seoul, depending on the positions of those who were involved with. The Qing emperor in Beijing and Chosŏn king in Seoul saw the Tumen and Yalu Rivers as an implement to ensure the authority of the suzerain court and the loyalty of tributary court. The control of borders and punishment of trespassers were important elements of the power of the Qing emperor and Chosŏn king. For the residents of this area, the Tumen River area was a trading space in which articles could be purchased based on contacts; meanwhile, for local officials, it was an area in which close cooperation with the officials from the adjacent country was needed in order to implement the orders of the central government. For local residents and officials, the Tumen River was as such a detailed and physical space rather than an abstract and political line. Rather than a space in which the will of the central power was unilaterally conveyed and penetrated, the borderland known as the Tumen River and Hunchun was a space in which various classes of people expressed and negotiated their desires.

Keywords: Hunchun, borderland, trespassing, Kyŏngwŏn border market, tributary relationship 
<국문초록>

\section{훈춘, 18 세기 청-조선의 국경지대}

김선민 (고려대학교 민족문화연구원 부교수)

본고는 1749 년 훈춘인근에서 일어난 살인사건을 통해 청-조선관계의 다양하고 복합적인 측면을 검토한다. 청인이 두만강을 사이에 두고 조선인과 물건을 매매 하다가 죽임을 당한 이 사건에는 국경지대에 거주하는 현지인들, 양국의 경계를 수비하는 지방의 관리들, 그리고 중앙의 청황제와 조선국왕이 모두 개입되어 있 었다. 그러나 이 사건은 두만강, 훈춘, 북경과 한양에서 관련자의 입장에 따라 각 각 다르게 인식되었다. 북경의 황제와 한양의 국왕은 두만강과 압록강에서 각각 종주국의 권위와 조공국의충성을 확인하고자했다. 경계를 통제하고 범월을 처벌 하는 일은 청황제와 조선국왕이 자신의 힘을 표현하고 유지하는데 매우 중요했 다. 현지의 거주민들에게 두만강 너머는 사람들과 접촉하여 물건을 매매할 수 있 는 교역의 공간이었고, 지방의 관리들에게는 중앙의 명령을 수행하기 위해 인접 국의 관리들과 긴밀히 협조해야 할 관할지역이었다. 현지의 거주민과 관리에게 두만강은 추상적이고 정치적인 분리선(divided lines)이 아니라 구체적이고 물질 적인 공간(space)이었다. 두만강을 사이에 두고 전개되었던 청인과 조선인의 다 양한 접촉과 교류의 양상을 검토함으로써 중앙중심적이고 위계적인 조공관계의 정형화된 이해를 비판적으로 재검토하고, 청과 조선이 맺어온 다층적이고 복합적 인 관계를 새롭게 이해할 수 있을 것이다.

주제어: 훈춘, 국경지대, 범월, 경원개시, 조공관계 
